\title{
Strengthening Community Legal Awareness Toward Consumer Protection Laws Through the Utilization of Information Technology
}

\author{
Anajeng Esri Edhi Mahanani1*, Firza Prima Aditiawan², Teddy Prima Anggriawan ${ }^{1}$ \\ ${ }^{1}$ Faculty of Law, Universitas Pembangunan Nasional "Veteran" Jawa Timur, Indonesia \\ ${ }^{2}$ Faculty of Computer Science, Universitas Pembangunan Nasional "Veteran" Jawa Timur, Indonesia
}

${ }^{*}$ Corresponding author:

E-mail:

anajengmahanani.ih@upnjatim.ac.id

\begin{abstract}
The development of information technology has had a major impact on the development of the business world. Types of businesses are increasingly diverse, including the types of businesses online. This development is increasing with positive and negative influences in 2020 . However, at the beginning of 2020 too, the world economy was shifting due to health issues, namely the covid-19 virus. This health issue has a major influence on the business world online, many cases of business buying and selling of non-National Food and Drug Agency products are even far from the quality they should be. This is only one example of a potential violation of consumer rights. This research aims to disseminate information technology-based media related to the enactment of Law Number 8 of 1999 concerning Consumer Protection. This socialization is packed with technological developments, and a touch of humanism in society and industrial development 5.0, namely through androidbased applications. This research is expected to be a form of the contribution of UPN "Veteran" East Java to the local community, nation, and state. In particular, it is helping to reduce violations of consumer rights, and strengthening public legal awareness regarding consumer protection.
\end{abstract}

Keywords: Technology Information, Covid-19, Consumer Protection

\section{Introduction}

Micro-level economic problems, often occur between business actors and consumers (Zimmermannová, 2020). The trading business, which was originally founded on the civil concept, has also shifted to the concept of crime, especially when it is linked to economic crimes. Many types of crime are directly proportional to the development of digital communication information technology, which brings this microeconomic practice to the realm of digital or commerce online. Economic crimes, which were previously carried out conventionally, have developed into modern economic crimes online.

There is a relationship between the economic curve related to the health problem of the Covid19 pandemic with the economy's progress and even the increase in violations of consumer rights. In widespread concerns over the spread of the Covid-19 virus, many business actors, it can even be said that "impromptu" business actors who carry out buying and selling online are mainly medical tools, goods, and materials which are claimed to be very useful to prevent and overcome the Covid-19 virus. In almost every story on Whatsapp and other social media, the status of business actors is found in trying to sell, for example, disinfectants, hand-sanitizers, rubber/latex gloves, masks, and so on at prices higher than normal or usual prices.

The problems do not stop here, many of these products are packaged in unbranded packages, the medical composition is unknown, even without the existence of BPOM (Britton et al., 2018).

\section{How to cite:}

Mahanani, A. E. E., Aditiawan, F. P., \& Anggriawan, T. P. (2021). Strengthening community legal awareness toward consumer protection laws through the utilization of information technology . $5^{\text {th }}$ International Seminar of Research Month 2020. NST Proceedings. pages 1-9. doi: 10.11594/ nstp.2021.0937 
This is what we can then conclude, that there has been a massive consumer violation, clearly displayed, but without good control from the consumers themselves and even the government. The current government is more focused on efforts to prevent and control covid-19, and consumers who are also focused on getting goods that can make themselves feel safer in the health sector, overriding than the quality and quality of the medical equipment, goods or materials purchased. Early March 2020, the Bandung Police, West Java, raided a recycled mask factory. This recycled mask factory business was allegedly operating quickly after the announcement of the first Covid19 case in Indonesia

This case further strengthens allegations of violations of consumer rights that can occur through the pattern of "impromptu" business actors who take advantage of the Covid-19 pandemic case to sell medical equipment, goods, materials without including composition to test product quality (News.detik.com, 2020).

Given the possibility of violations of consumer rights, and this pattern may even develop in similar cases in the future, researchers are interested in providing education related to consumer protection law policies. The consumer protection law policy in Indonesia at the level of the Act is regulated in Law Number 8 of 1999 concerning Consumer Protection. It is an old law product, but many people do not understand it, mainly consumers.

Knowledge regarding this consumer protection law policy must be implemented quickly, effectively, and efficiently (Rosadi \& Tahira, 2018). The existence of legal products that have been in the form of written regulations, and in the language of law which is often not easy to understand by ordinary people of law, will complicate and suppress the level of people's desire to know and understand. Packaging legal products about consumer policies through an application that not only summarizes but also categorizes rules based on the categorization of needs that the audience wants to know, as well as opens a question and answer space for audiences who want to understand more about the substance and practicality of consumer protection law policies, is an effort practical and progressive.

\section{Material and Methods}

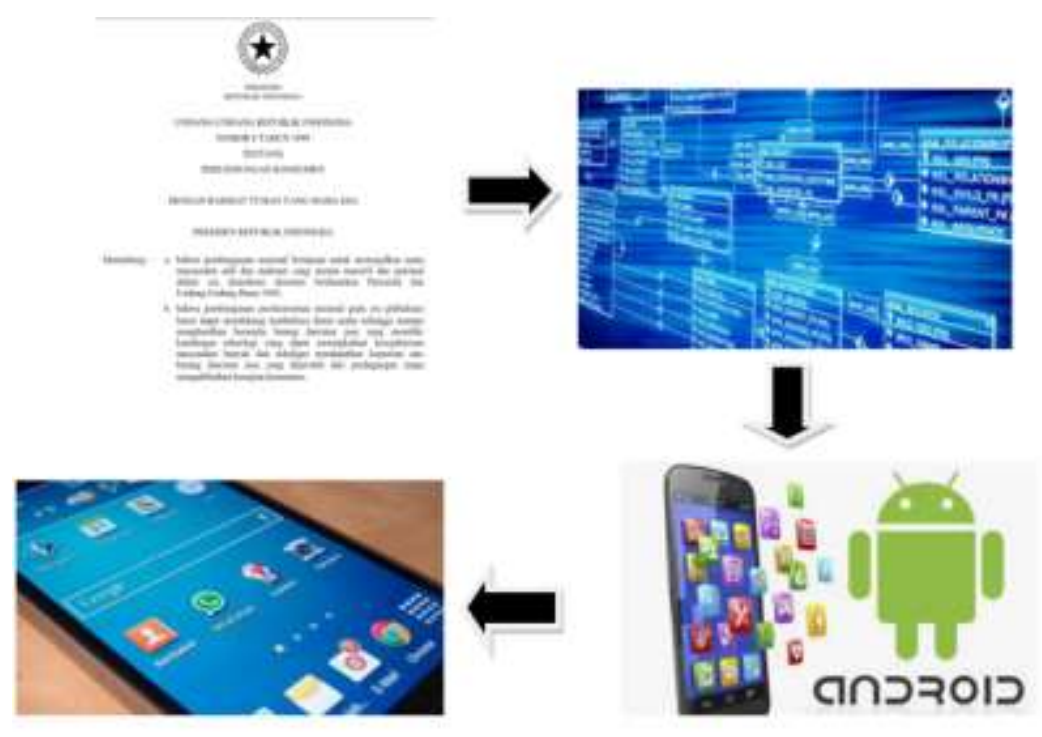

Figure 1. The legal products 
In this study, researchers applied the waterfall method which has been widely used for the development of software systems that are widely used in software development projects. In using this method, it is necessary to have a systematic approach in developing the software system.

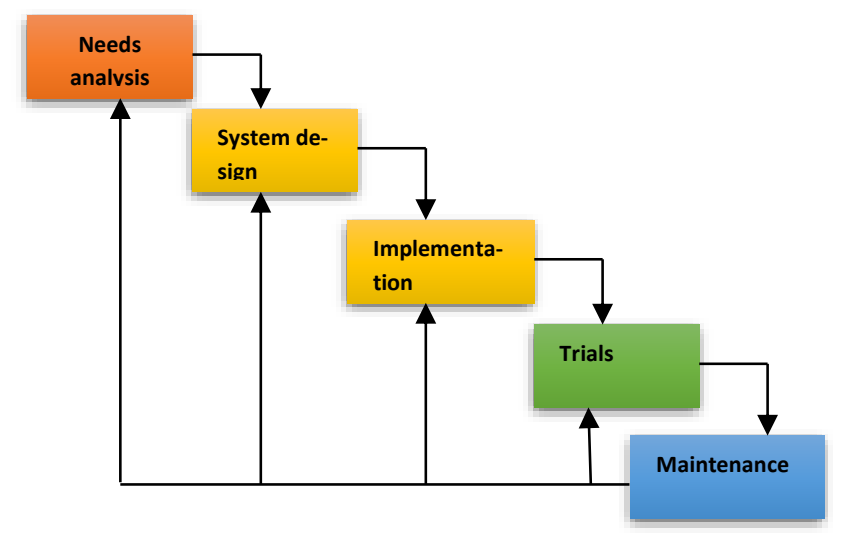

Figure 2. Waterfall's method

The flow of implementing this system begins with data retrieval and then processed in the database system. If the database has been formed, the next step is to make a design. The next stage is to conduct trials to measure the effectiveness of the system in the process of using it. Evaluation is done by looking at the system output with results validated by experts. The two results will be compared and accuracy measurements will be made. This stage is the stage to carry out the validation process for applications that have been made compared with experts.

\section{Results and Discussion}

Many factors influence that the law is not enforced or not obeyed or violated, among others, the first is the community factor. The community does not know the existence of law, the community knows about the existence of law but does not understand it, the community knows and understands the law but lacks legal awareness. The two factors are law enforcement. Law enforcers do not understand the existence of law, law enforcers understand the law but lack awareness to act according to the law. The third factor is the law itself. What then becomes the focus of research in this study are the factors of the community who do not know and understand the law.

Legal awareness itself is one's awareness without any pressure, coercion, or orders from outside to comply with the applicable law. With the running of legal awareness in society, the law does not need to impose sanctions. Sanctions are only imposed on citizens who are proven to have violated the law, which contains orders and prohibitions. The law tells us which actions are against the law which if done will get the threat of legal sanctions. Actions that are against the law are of course considered to be against the law so that they are threatened with punishment. Legal awareness is an abstract conception in humans of the desired harmony between order and order. So legal awareness, in this case, is awareness to act following legal provisions. This legal awareness in society is a bridge that connects regulations with the legal behavior of community members. It can be understood that no matter how good the regulations are made if they are not supported by the legal awareness of the community it will be useless. Legal awareness itself is closely related to the issue of legal culture in the form of values, views, and attitudes that affect the operation of the law (Candra, 2020). Building public legal awareness is not an easy matter. It is very different from building physical facilities, such as facilities and infrastructure. Especially with the background of the Indonesian people who have various ethnic, religious, economic, cultural, and educational backgrounds. This is because it builds legal awareness regarding one's inner processes and inner processes between people who are different from one another. Because it also involves experience, knowledge, social life, appreciation of legal norms, and the background of each person. 
Technological developments have greatly helped many advances in society, one of which is to provide education in conveying a rule or policy to make it easier to accept. This positive impact then becomes an answer to the negative impact of the application of the principle of legal fiction in society. The principle of legal fiction demands that the public know the contents of the law that has been published so that it has an impact on the creation of an understanding of the law and legal compliance which is known as legal awareness.

The existence of variations in the relationship between the variable knowledge of legislation and the compliance of community members is motivated by the state of the relationship between the variable of statutory rules and other social rule variables that exist in the community. There are people/members of the community who, although they do not know and do not understand the material of legislation, have implemented the law, this is due to the many similarities between legal norms or rules (legislation) and other social norms (religious norms, morals, courtesy) which the local community has known, understood, and obeyed such as environmental laws, laws regarding the prohibition of stealing, cultural heritage laws, environmental safety laws, etc. It is a fact that local wisdom is something that plays a role in encouraging the realization of community legal awareness. There is a tendency that the similarity in the content of norms between law and existing norms of local community regulations that are obeyed by the community will facilitate the socialization of the law.

The process of disseminating or socializing this law is known as the promulgation of the law, as introduced by Asshidiqie (2005). The promotion of law should be carried out to deal with the flood of regulations (hyper-regulation). What has become known in terms of information technology is the use of digitization.

In utilizing information technology or digitization for the dissemination of legal products, which are then packaged by researchers in the form of applied applications, it is formed based on the following principles:

a. Principle of Integrity / Synergy.

The development and application of information technology must be able to integrate all available information in a detailed and informative manner.

b. Human Resources Quality Improvement Principles.

Efforts must be made to develop and apply information technology to strengthen and improve the quality of human resources in the context of building a law-conscious society.

c. Principle of Benefits / Usability.

The development and application of information technology must be endeavored to be more efficient and economical as well as highly efficient. The system must be able to present the required information quickly, accurately, and on time.

d. Principles of Safety and Reliability.

The reliability of the development and application of information technology must be guaranteed so that it is always ready to use following the level of service required.

e. Legality Principle.

The development and application of information technology must comply with the law, in this case, must respect intellectual property rights (HaKI), copyright, and other rights that are recognized by law and applicable laws.

f. Principle of Equal Access Rights.

The development and application of information technology must be able to guarantee and provide equal access rights to information on legal products that are open to the public.

g. The Principle of Flexibility.

The development and application of information technology must be carried out in a modular and sustainable manner (incremental development) to ensure the level of flexibility of the system against changes.

h. Principles of Open System, Open Source, and Legal software. 
The development and application of information technology is carried out using an open system standard, making it possible to more efficiently integrate the various technologies available today.

It has been explained in the background of the problem, that the focus of digital socialization is the legal product of the Consumer Protection Law. This is based on the prevalence of violations of consumer rights, especially the risk of rights violations during a pandemic, where online buying and selling is increasingly prevalent. Given the possibility of violations of consumer rights, and this pattern may even develop in similar cases in the future, researchers are interested in providing education related to consumer protection law policies. The consumer protection law policy in Indonesia at the level of the Act is regulated in Law Number 8 of 1999 concerning Consumer Protection. It is an old law product, but many people do not understand it, mainly consumers.

The substance of the consumer protection law policy should be understood by the public as a whole, so that people who are positioned as consumers can understand their rights, can know the efforts in filing lawsuits against violations of consumer rights, and know about dispute resolution efforts. On the other hand, the community as business actors, even "impromptu" or situational business actors such as in the case that coincided with Covid-19, can know and understand the obligations of business actors not to violate consumer rights. This research then formulates innovations by utilizing information technology tools to create smart and law-aware applications, especially consumer protection law policies, which are more practical, innovative, progressive, effective, and efficient.

The program which is then used in the context of socializing this legal product is through the Android application. The first advantage of this Android OS is that it is an operating system that is open source. This is because Android is a Linux-based operating system, so it is an OS that is easy to develop because it has an open-source system. The Main Menu interface is the initial display of the application when it is run on a mobile device. This page appears when the user first opens the application.

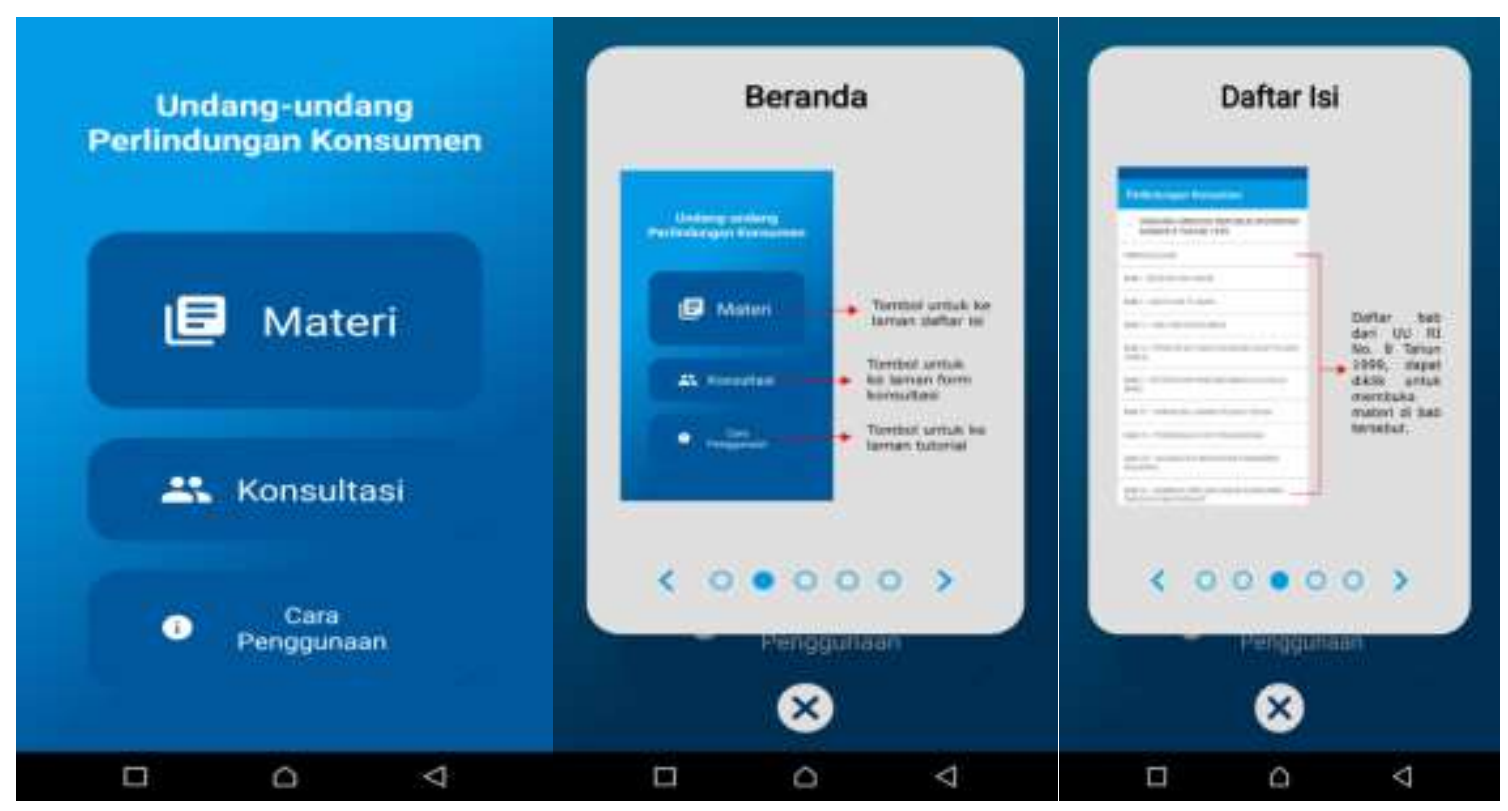




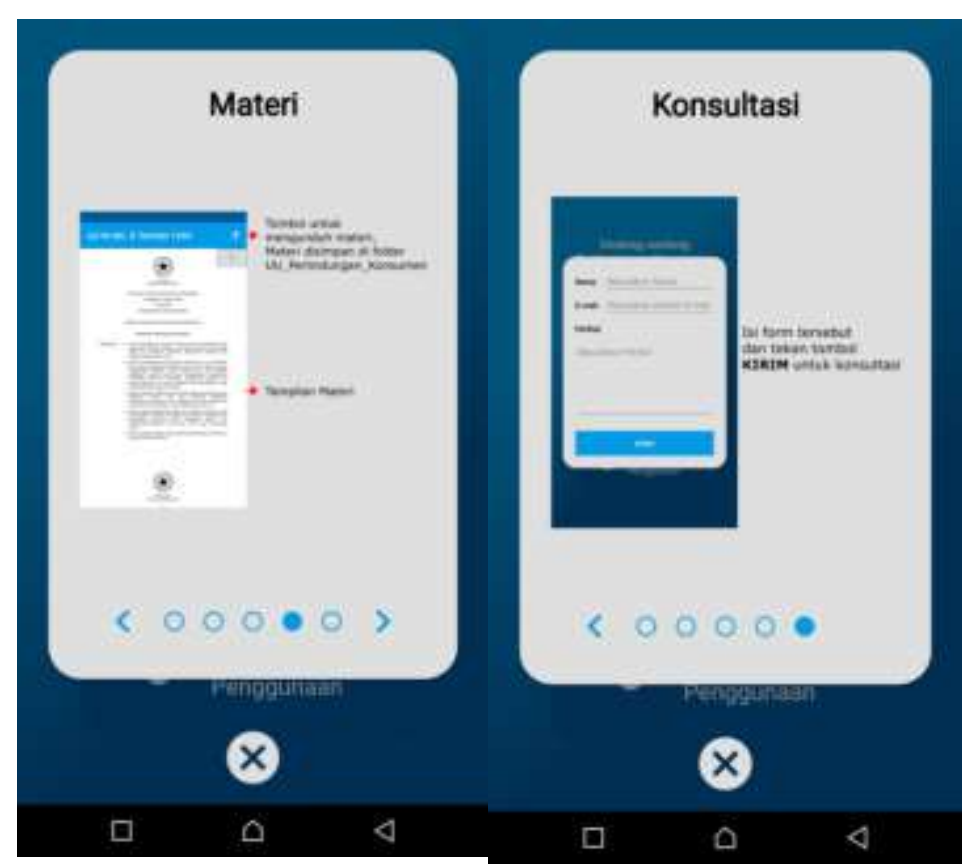

Figure 3. The application of Undang-Undang Perlindungan Konsumen

All buttons and subsystems in the application work and function properly after testing. Also, by testing on smartphones with different OSs shown in table II, the testing on each smartphone gave good results during the trial. Thus it can be concluded that the application can run properly.

\section{Conclusion}

Based on this description, the focus of digital socialization is the legal product of the Consumer Protection Act. This is based on the development of information technology which has a major influence on the development of the business world. Types of businesses are increasingly diverse, including the types of businesses online. This development is increasing with positive and negative influences in 2020. However, at the beginning of 2020 too, the world economy was shifting due to health issues, namely the covid-19 virus. This health issue has a major influence on the business world online, many cases of business online buying and selling of non-BPOM products are far from the quality they should be. This is only one example of a potential violation of consumer rights. This study aims to disseminate information technology-based media related to the enactment of Law Number 8 of 1999 concerning Consumer Protection. The substance of the consumer protection law policy should be understood by the public as a whole, so that people who are positioned as consumers can understand their rights, can know the efforts in filing lawsuits against violations of consumer rights, and know about dispute resolution efforts.

\section{References}

Asshidiqie, J, (2005). Hukum tata negara dan oilar-pilar demokrasi: Serpihan pemikiran hukum, media dan hak asasi manusia. Jakarta: Konstitusi Press.

Britton, K., Koseki, S., \& Dutta, A. (2018). Expanding markets while improving health in Indonesia: Private health sector market in the JKN Era. Washington, DC: Palladium, Health Policy Plus; and Jakarta, Indonesia: TNP2K.

Candra, S. (2020). Kesadaran hukum masyarakat, hukumonline (08 Mei 2020,) diakses pada 02 September 2020.

https://news.detik.com/berita-jawa-barat/d-4928157/polisi-bongkar-pabrik-masker-daur-ulang-di-bandung, diakses pada tanggal 21 Maret 2020, pukul 11.41 WIB.

Rosadi, S. D., \& Tahira, Z. (2018). Consumer protection in digital economy era: Law in Indonesia. Yustinisia, 7(1), 111-119.

Zimmermannová J. (2020) Methods in microeconomic and macroeconomic issues. In: Pászto V., Jürgens C., Tominc P., Burian J. (eds) Spationomy. Springer, Cham. https://doi.org/10.1007/978-3-030-26626-4 5 